\title{
THE IMPORTANCE OF MATIJA MURKO'S RESEARCH \\ FOR UNDERSTANDING THE MUSICAL TRADITION \\ OF BOSNIA AND HERZEGOVINA ${ }^{1}$
}

DRAGO KUNEJ, JASMINA TALAM AND TAMARA KARAČA BELJAK

Prispevek predstavi raziskovanje in zvočno dokumentiranje Matije Murka v Bosni in Hercegovini v letih 1912-1913 in 1930-1931, pri čemer poudari pomen Murkovih raziskav in terenskega gradiva za razumevanje nekdanje in današnje pesemske tradicije $v$ Bosni in Hercegovini in njenih transformacij $v$ historični perspektivi. Gradivo omogoča tudi pomembna spoznanja o izvajanju epskih pesmi ob igranju gusel, sevdalink ob spremljavi violine in petje t. i. ravnih pesmi. Murkovi posnetki so veckrat tudi najstarejsi in hkrati edini zvočno dokumentiran dokazo obstoju nekaterih preteklih glasbenih praks.

Ključne besede: ljudske pesmi, fonografski posnetki, terenske raziskave, zvočni dokumenti, epske pesmi, gusle in guslarji
The paper presents the research and sound documentation carried out by Matija Murko in Bosnia and Herzegovina in 1912-1913 and 1930-1931. It focuses on the importance of Murko's research and his collected field material in gaining a historical perspective on the past and present musical traditions of Bosnia and Herzegovina and its transformations. Murko's recordings provide some significant insights into the singing of epic songs accompanied by gusle, the sevdalinke performed to the accompaniment of the violin, and the singing of ravna songs. Murko's recordings are often the oldest and - in some cases - the only recorded evidence of the existence of certain musical practices. Keywords: folk songs, phonograph recordings, field research, sound documents, epic songs, gusle and gusle players

\section{INTRODUCTION}

Bosnia and Herzegovina has attracted the attention of many foreign researchers ever since the nineteenth century. Foreign researchers' studies of folk art in Bosnia and Herzegovina, as well as throughout the rest of the Balkans, sparked interest in a "new" and mostly unknown artistic tradition. Western European researchers delved into exploring a culture that was considered exotic in some ways. Particular attention was paid to the relationship between the rural tradition, which conserved more archaic features, and the urban tradition, which had been exposed to the process of acculturation during the long Ottoman rule. Gerhard Gesemann, a German folklorist of Slavic descent, gave the following reasons for why the Bosnian tradition was an attractive research subject:

For four hundred years, the Balkans were covered with a dark curtain. Everything that happened in this part of Europe was a secret. Only the reports about wars and protests revealed some details about life in this area. More than one hundred years ago this curtain started to become transparent, and that is when Europe, as a manifestation of the hitherto unknown life in the Balkans, sat in the first row and

1 This paper is part of an ongoing bilateral research project Challenges and Perspectives of Computerization, Digitization, and Dissemination of Archival Collections of Slovenian and Bosnian researchers. 
heard a song. It appeared so fresh it dispersed the beauty of the traditional soul, emerging from the inborn strength. Europe's first view of the Balkans was thus of the area's ethnography. The constant patriarchy, as the carrier of those ethnographic particularities, formed the moral spine of the people and contained such strong moral and ethical values that it fascinated all the great spirits of Europe. (K. A. 1937)

Significant data on Bosnian folk art and also more general information on this ethnically diverse culture was collected by Friedrich Krauss, Luka Marjanović, Matija Murko, Gerhard Gesemann, Kurt Huber, Walther Wünsch, Felix Hoerburger, Milman Parry, Albert Lord, and other researchers whose focus was often on studying and collecting folk music. Until the early twentieth century, Bosnian folk music researchers mostly focused only on song lyrics, not their melodies. Only a few, such as Ludvik Kuba and Franjo Kuhač, documented their melodies using music notation as well.

With the advent of field recording devices in the early twentieth century (especially phonographs), researchers also began documenting folk music practices using sound recording devices. The first scholarly sound recordings of Bosnian music date from 1908 and were made by the Lithuanian linguist and ethnographer Eduard Wolter (1856-1941) for the Berlin Phonogram Archive ${ }^{2}$ and by the Austrian linguist Julius Subak (1872-1936) for the Imperial Academy of Sciences in Vienna. ${ }^{3}$ In the following years, recordings of Bosnian music in different contexts were made by Matija Murko (1861-1952), Lea Hajek (1887-1975), a scientific expedition of the special commission of the Southeast Committee of the German Academy in Munich headed by Gerhard Gesemann (1888-1948), and American researchers Milman Parry (1902-1935) and Albert Lord (1912-1991).

Of the research mentioned above, Matija Murko's studies are particularly significant. They were conducted very systematically at various times (1909, 1912, 1913, 1930, and 1931) and in various localities. Murko consistently documented all of his work, including its technical aspects, extremely well. This turned out to be extremely useful in analyzing his collected material. In his field research, he often used new methodological approaches and technical devices, such as sound recordings and photography. Financial and logistical limitations prevented him from using a recording device during all of his field research trips. ${ }^{4}$

2 The Berlin Phonogram Archive holds four of Wolter's recordings of Bosnian music: three recordings by guslar Rizvan Kadrovic and one by guslar Pero Dragoje from Ilidža.

3 During his stay in Sarajevo, Subak made five phonograph recordings in the Sefardic Ladino language (Judeo-Spanish), two of which include songs recited and sung by Abraham A. Cappon (age 55), a romantic song performed by Rafael Atias (age 44), a moralistic song sung by Moshe ben Rafael Atias (age 65), and a Zionist hymn composed by Abraham A. Cappon and sung by Blanca Levi (age 17). The additional documentation includes protocols with informant- and recording-related information, as well as photographs by Abraham A. Cappon and Moshe ben Rafael Atias (Talam 2016).

4 From 1909 to 1932, Matija Murko went on eight field research trips to study folk epics in the Balkans, and during six of these trips he made sound recordings. In Bosnia and Herzegovina, he made phonograph recordings in 1912, 1913, 1930, and 1931. 
Murko's sound recordings can be divided into two groups: the Vienna material recorded during his trips in 1912 and 1913, and the Prague material recorded during trips from 1930 to 1932. The Vienna material was recorded using an archival phonograph (Archiv-Phonograph) borrowed from the Phonogram Archive at the Austrian Academy of Sciences 5 ; eighty-two discs were recorded altogether. The Prague material was recorded using two Edison phonographs. According to his notes, Murko recorded 349 cylinders. Unfortunately, many of the sound recordings from both periods were later damaged, destroyed, or lost. The aim of field research with sound documentation, the recording process, and the course of recording was similar during all his trips. The two groups of recordings, however, differed in the type of recording devices and the sound recording carriers used: phonograph wax discs and wax cylinders. The institutions that ended up storing the recordings also differed; the Vienna recordings remained in the hands of an archival institution dedicated to preserving and processing sound material (the Phonogram Archive at the Austrian Academy of Sciences in Vienna), whereas the Prague recordings were maintained in the archival care of various institutions with less consistent professional standards of care (the Slavonic Institute in Prague; the Yugoslav Academy of Sciences and Arts, and the present-day Croatian Academy of Sciences and Arts).

Murko's research and fieldwork material remained neglected by researchers in Bosnia and Herzegovina for decades and hardly any ethnomusicologists were familiar with it. Recent work on Murko's Phonogram Archive sound material ${ }^{6}$ has opened new perspectives on the importance of his research and sound documentation in Bosnia and Herzegovina. The sound recordings made during these field studies proved to be the first quality recordings to document musical traditions of Bosnia and Herzegovina that are no longer present in folk practice. Also, some of the musical forms recorded in Murko's recordings have undergone significant transformations, opening up opportunities for comparative research.

The paper focuses on a comprehensive analysis of Matija Murko's sound documentation work in Bosnia and Herzegovina and an evaluation of the preserved sound recordings, which can serve as exceptional documentary sources, especially in combination with comprehensive handwritten documents and other material collected during fieldwork. There is still much to be learned from Murko's recordings from Bosnia and Herzegovina, because in the past these recordings were not available to Bosnian researchers. In his written works, Murko came to certain conclusions regarding the origins of epic songs, information regarding singers, and so on. Bosnian ethnomusicologist Cvjetko Rihtman (1953) and folklorist Tvrtko Čubelić (1971) disagreed with Murko's views. On the other hand, Đenana Buturović (1991)

5 It is not clear whether Murko was equipped with a Type III archival phonograph or if he already had access to a Type IV (cf. Lechleitner and Spitzbart 2017).

6 In 2014, the Phonogram Archive in Vienna and the Institute of Musicology of University of Sarajevo's Academy of Music launched the project "The Matija Murko Collection (1912/13)," with the participation of Tamara Karača Beljak, Franz Lechleitner, Gerda Lechleitner, Jasmina Talam, and Johannes Spitzbart. This project resulted in the publication Epic Folk Songs from Bosnia and Herzegovina: The Collection of Matija Murko (1912, 1913) (Liebl and Lechleitner 2017). 
considered Murko the founder of field research and considered his work to be invaluable for further study of the Bosnian epic. Murko had opened a new chapter in the study of epics. The paper aims to draw attention to the importance of Murko's research and his collected fieldwork material in understanding the past and present musical traditions of Bosnia and Herzegovina and their transformations from a historical perspective.

\section{THE FIRST FIELD RESEARCH BY MATIJA MURKO IN BOSNIA AND HERZEGOVINA}

Murko carried out his first field research in Bosnia and Herzegovina in 1909, following the previous research by Luka Marjanović. ${ }^{7}$ While conducting this particular study, Murko did not use a sound recording device or photography equipment yet. The aim of his research was to study the Muslim folk epics performed by established singers. Murko's intention was to record songs performed by Bećir Islamović, and later also by other singers, which were documented by Luka Marjanović. Murko's son Vladimir later wrote that "on his first journey through the Bosnian Frontier (Bosanska Krajina) in 1909, my father worked without a phonographic device, mainly with Muslim singers, some of whom had sung their songs for the songbook released by the the Croatian Society (Matica hrvatska) twenty years earlier, and even then he noticed considerable differences in length and diction; much less, however, in the content of the same songs sung by the same singer" (Murko 1963: 113).

At the International Congress of Historical Sciences in Vienna in 1908, Murko presented the results of his first field research in the work titled "The Folk Epic of Bosnian Muslims" (Die Volksepik der bosnischen Mohammedaner; 1909). His conclusions relate primarily to the way the songs were performed and the relationship between the Muslim and Christian epics. Murko found that singers change "their songs, and that this is influenced by the circumstances in which they sing" (Murko 1951a: 11). He also pointed out the importance of exploring the Muslim epics in relation to the Christian ones. In his opinion, the epic poetry of Muslims from Bosnia and Herzegovina, especially those from its northwestern corner between Croatia and Dalmatia, could best be used to learn more about the original South Slavic epics: above all, the epic poems documented in a collection by Luka Marjanović. He supported the view of Croatian ethnomusicologist Franjo Kuhač, who argued that the forms of Muslim epic folk songs were no different from those of Christian ones and that they were not as dreamy as Arabic and Turkish epics, but quite realistic and "completely identical with Christian, Orthodox, and Catholic ones" (op. cit.: 11). Some differences were noticeable only in the songs' texts. He concluded that Muslim

7 Luka Marjanović (1844-1920) graduated from the Faculty of Law in Zagreb and then completed his doctorate in Vienna. He was a professor at the Faculty of Law and the rector of the University of Zagreb from 1889 to 1890 . Thanks to the support of the Croatian Society (Matica hrvatska), he collected a large number of epic poems from the Bosnian Frontier (Marjanović 1898). 
and Christian epics could not be viewed in isolation, but nevertheless pointed to researchers' insufficient attention to the study of Muslim epics (Talam and Karača Beljak 2016: 511). He believed that this was the result of "unscientific issues"; these included the relationship between Sarajevo, Zagreb, and Belgrade, which was characterized by mutual jealousy and led to Serbian and Croatian quarrels over the ethnicity of Muslim songs, thereby shifting attention away from the songs themselves and their values (Buturović 1991: 12).

\section{RESEARCH IN 1912 AND 1913}

Two years later, Murko received a scholarship from the Balkan Commission of the Austrian Academy of Sciences in Vienna for the study of epics in Croatia and Bosnia and Herzegovina in the summer of 1912 and $1913 .{ }^{8}$ He extended his research to national minorities, especially the Roma. In addition to the epics, Murko became interested in lyrical songs, as well as the instruments that sometimes accompanied that type of singing. ${ }^{9}$ Both Murko's field research trips took place during the summer holidays. Murko wrote two detailed reports about his research, experiences, and the results of his work with the phonograph (Murko 1912; 1915). The reports also detail the purpose of using a phonograph for field research, as well as its advantages and disadvantages. Each report is accompanied by a list of all the recordings, each containing a description of the content, information on the singers, and individual content-related and technical notes. On these trips, Murko used a special archival phonograph from the Phonogram Archive at the Austrian Academy of Sciences in Vienna, recording a total of eighty-two records.

He had decided to use sound recordings based on the reports written by Milan von Rešetar and Paul Kretschmer about their first field recordings (1901), made with a Type 1 archival phonograph, in which they recommended the use of phonographs mainly for studying folk songs. At first, Murko wanted to use the phonograph primarily to be able to record epic songs in their entirety and word by word while being performed. In previous field documentation, epic song lyrics were either dictated or only small segments of the performed songs were written down, because even the most skilled stenographers were unable to write everything down during the singing process. Murko wanted to be well prepared for the field recordings and so he made some test recordings using the archival phonograph at the Indo-European Institute of the University of Graz, where he was employed at the time. In doing so, he realized that he would be unable to fully achieve his primary goal of recording the songs in full, because some epic songs consisted of over 1,000 verses and he could only record at most twenty to thirty verses on a single record.

8 Murko also obtained funding for research to be conducted in 1914 but was prevented from carrying it out by the First World War.

9 He described his observations on folk musical instruments in the article "Gusle i tamburica sa dvije strune" (Murko 1924). 
It would thus take over 350 discs to record a single long epic song; that is, an amount that exceeded the total of all the discs recorded by Phonogram Archive in Vienna in all their recordings throughout the year. For this reason, Murko abandoned his original idea of recording entire songs and decided to use the phonograph mainly to identify the way songs were performed and to study the number of syllables in a verse, the rhythm and its relation to the word accent, any special dialect features, and other speech characteristics (Murko 1912: 1).

In accordance with the instructions and practice of the Vienna Phonogram Archive, Murko wrote protocols for each recording. The protocols contained relevant information about the performers (name, year and place of birth, ethnicity, etc.), recording information (date, time and place of recording, genre), song lyrics (both spoken and sung) and other relevant information. Further information on performers is provided in the "research report" field. Thus, more detailed data on the song performances were documented, some expressions used in local dialect were explained for performing styles of parts of a song (naoštraj, zaoštraj: a shorter break in performance), song types (epic, lyric-epic, lyric), instruments accompanying the singing (the single-stringed gusle, the two stringed tambura, violin), as well as information on the individual releases in which the recorded songs were previously published.

During 1912, Murko made forty-six recordings with twenty different performers in northwestern Bosnia. Some of the recordings were technically inferior, and so after listening to them, he indicated that there was no need to make metal matrices out of them (Murko 1912: 10). Accordingly, the Phonogram Archive in Vienna now holds twenty preserved metal matrices featuring seven recorded epics (some in sequels) and four lyric songs.

In the summer of 1913, Murko went on another similar field research trip; he again used an archival phonograph and made recordings in Sarajevo and Herzegovina. He recorded a total of thirty-six phonograph records with twenty-six epic songs, two lyric songs, three stories about the singer's life, and one guslar melody. All these recordings have been preserved on metal matrices. In his field research report Bericht über eine Reise zum Studium der Volksepik in Bosnien und Herzegowina im Jahre 1913 (Murko 1915), Murko also wrote down some very important data on persons that assisted him during the research, instruments, melodic forms, and additional data on informants.

Working with the archival phonograph was challenging: Murko was unhappy about the weight of the device and all the necessary equipment $(73 \mathrm{~kg})$, which was packed in three individual containers. This made for difficult horse-drawn transportation, as well as time-consuming preparations and the recording process itself. Nevertheless, it was the sound recordings that contributed to new findings in folk epic research.

Murko repeatedly commented on the technical quality of his recordings, as he checked them on a regular basis while doing fieldwork, noting down all his comments in the accompanying protocol. In 1914, he also listened to his recordings, comparing them to the protocol notes. He found that the recordings on positive wax casts produced from the metal matrices (nickel-plated copper negatives) were of somewhat lower quality than the originals and that the lyrics were occasionally more difficult to understand. He did, 
however, also point out that the lyrics of epic singers were difficult to understand; they were, in fact, often understood only by those locals who had not lost their sense of folk parlance. In spite of its shortcomings, Murko believed the phonograph to be the most suitable device for recording and studying folk songs (Murko 1915: 9).

During the Second World War Murko's original wax disc recordings were destroyed, as were all other original recordings housed in the Vienna Phonogram Archive, but the metal copies (nickel-plated copper negatives) and the related protocol documents survived.

\section{RESEARCH IN 1930 AND 1931}

After a seventeen-year hiatus, Murko returned to Bosnia and Herzegovina. Murko's trips around the Balkans in the 1930-1932 period were made possible by the increased efforts of the Charles University in Prague and the Czechoslovak Ministry of Education to advance Slavic studies and, even more so by the establishment of the Slavonic Institute in 1928. During the first few years of its existence, the Institute granted some substantial travel scholarships and also covered the full cost of photography and sound recording for Murko's field research trips.

Based on positive experiences from his prior research, he took sound recording devices with him on this research trip too. To facilitate documentation, and probably also due to Murko's age ${ }^{10}$ he was assisted by his two sons, Vladimir and Stanko, who were in charge of sound recording and photography. The sons noted down information about the sound recordings on the cylinder boxes and in special notebooks; using the information provided by the performers or the listeners present, or relying on their own judgement, they wrote down mainly the song titles. The sequence of the listed songs follows the information about the research journey and various details are added for each of the recordings: information about the performer, the song title, the place of recording, and often also the performer's place of origin, as well as various notes (Murko 1951b: 540). The list reveals that 208 cylinders were recorded during the 1930 trip, ninety-six in 1931, and forty-five in 1932, for a total of 349 cylinders. ${ }^{11}$

10 During the field research in question, Matija Murko was sixty-nine to seventy-one years old.

11 During these research trips, Murko came into contact with many informants and collected a great deal of fieldwork material, sound recordings, photographs and data. He wanted to process and publish the collected material as soon as possible, but due to a large amount of work overall and various problems with publishing, the material was not published until 1951. The comprehensive study was titled Tragom srpsko-hrvatske narodne epike: Putovanja u godinama 1930-1932 (In the Footsteps of Serbo-Croatian Folk Epic: The Trips of 1930-1932). In two volumes consisting of 940 pages, Murko discussed the field research material collected during these trips, documenting it extensively through various lists, explanations, and selected photographs. A special chapter was dedicated to the sound recording and photography. The chapter included detailed lists of field recordings with numerous notes and comments, as well as detailed descriptions of the singing style and the quality of the recordings. Much less attention, however, was devoted to performer-related information. 
Murko made sure to prepare well for the sound recordings on these trips. Because he wanted to use state-of-the-art recording technology, he inquired at various institutions about all sorts of recording devices, however, most of the information he obtained was of no use for his purposes. He found that the use of a gramophone, which would improve the quality of the recordings and make the lyrics easier to understand, was not suitable for several reasons; first and foremost, it required connection to electricity, on account of which he would be unable to carry out the planned research in the singers' everyday environments. With the help of the Berlin Phonogram Archive, he learned that a Berlinbased company was still producing old Edison phonographs, which were the only devices suitable for his intended research methodology. In early April 1930, he therefore travelled to Berlin to study the recording methods and to learn about the experience of the Berlin Phonogram Archive and the radio station at the Technical College in Potsdam. It was during this time that he made the final decision to use the Edison phonograph for his field research, so he purchased not only one, but two devices ${ }^{12}$ and ordered blank phonograph cylinders (Murko 1951a: 24).

Murko made recordings in Bosnia and Herzegovina during the first two years of his research, in 1930 and 1931. In 1930, he conducted field research in eastern Bosnia in Zvornik, Bijeljina, Brezovo Polje near Brčko, Tuzla, Kladanj, Srebrenik, Bratunac, and in 1931 in Višegrad, Goražde, Foča, Sarajevo and the surrounding area, Humac and Čapljina. During this research, he recorded forty-five cylinders with thirty-eight epic songs, four lyric songs, one humorous-protest song, one instrumental introduction on gusle, and one toast (Murko 1951a: 540-550). He made recordings in various places and on various occasions. In addition to the recorded material, he documented some valuable data on the way of life in certain local communities, folk instrumentalists as well as professional folk musicians, the ways they learned songs, the repertoire they performed, and the performing venues with special reference to cafés. It is important to mention that he often made comparisons with what he had noted during previous research trips (Murko 1913, 1951a).

Unfortunately, much of the recorded material has been destroyed and lost over the years. Thus, Murko's son Vladimir, who was involved in sorting out his father's papers after his death, and who paid special attention to his sound collections, later wrote that the sound recordings from 1930 to 1932 had suffered a rather grim fate. He saw this as a “sore point of Matija Murko's scholarly legacy” (Murko 1963: 112).

12 Since Murko was already well familiar with the singers having difficulties being interrupted and cut off while singing, he wanted to continue recording by means of a second phonograph when the recording time on the first one was over (a recording time of one cylinder is approximately 3-4 minutes). This allowed him to continuously record slightly longer sections of songs; e.g. in 1930, a song was recorded on seven consecutive cylinders. These recordings are especially interesting because they show a longer-lasting continuous performance than had never been recorded before (Murko 1963: 115). However, this recording method was used mostly in 1930, when not much attention was paid yet to economical use of cylinders. 
The collected material, including the sound recordings, was first stored at the Slavonic Institute in Prague, where Murko was active at the time. The earliest information concerning the preservation and storage of sound recordings can be found in the book Tragom srpsko-hrvatske narodne epike, in which Murko reports of unsuccessful attempts to "protect the fragile material on wax cylinders for more frequent use and for the foreseeable future" (Murko 1951a: 538). To this end, in 1933, the board of the Slavonic Institute turned to the best Prague-based company, Elektrotechna, but the company was unable to come up with a satisfactory solution. He made a similar observation in Spomini (Memoirs): "We did our best to preserve the wax cylinders, so they could be reinforced and used more often, but in vain" (Murko 1951b: 243).

Murko also reports (1951a: 538) that once recordings on wax cylinders were used for scholarly research it was recommended that they be galvanized (which offered "permanent" storage on metal negatives). ${ }^{13}$ On the initiative of Gerhard Gesemann, who studied many of Murko's recordings from the first trip (in 1930) already at the beginning of 1931, fiftythree cylinders were thus sent to Berlin to be processed at the Phonogram Archive. The selection of cylinders was made by Gesemann and Murko, but the list of cylinders sent has not been preserved. It is therefore not known which particular cylinders were sent to Berlin, but they were most likely the more successful and important recordings. Vladimir Murko's extensive inquiry into this material bore no fruit, and during later examinations of the sound material at the Berlin Phonogram Archive these cylinders could no longer be found. For this reason, they are not included in the 2000 and 2006 material inventories (cf. Ziegler 2000: 237; Ziegler 2006). According to some sources, these cylinders were destroyed during street fighting in the Second World War.

According to information Vladimir Murko obtained from Prague in 1960, the collection of cylinders had been transferred to the Slavonic Institute's new premises in 1955.

13 The Berlin Phonogram Archive holds a partially preserved correspondence between Gustav Becking, director of the Musicology Institue of the German University in Prague, and Erich von Hornbostel, the director of the Berlin Phonogram Archive, as well as between Murko and von Hornbostel. Admiration for Murko's research work and collected material is repeatedly emphasized in the correspondence from the 1930-1932 period. For instance, in a letter written by Becking to von Hornbostel in 1930, Becking wrote, "Murko has been traveling for a long time, visiting the most remote areas and bringing in a lot of material [...], something completely new. [...] The old man is extraordinary" (SMB 1930). A year later, when Murko went on another field research trip to the Balkans, Becking mentioned that "Murko returned to the Balkans with his phonograph and a large store of cylinders. Despite being seventy, he is tireless in his pursuit of collecting new material" (SMB 1931a). Von Hornbostel replied that he too "eagerly awaited" Murko's recordings, which were due to arrive at the Phonogram Archive soon after (SMB 1931b). Similarly, in his letters to von Hornbostel, Murko noted the first positive responses to his collected material; among other things, he mentioned that "Professor Becking liked last year's recordings very much" (SMB 1931c), and referred to other researchers' enthusiastic response to his work in subsequent correspondence too. For instance, in the 1931 lists of phonograms, he stated that other researchers were delighted with the singing of the aforementioned Ibrahim Vrabac. Prof. Becking described the phonogram number 28, which featured Azgin Marijan's song performed by Vrabac, as ganz kunstios ("real art”; Murko 1951a: 541). 
While stored there, several of the cylinders in question are believed to have been destroyed by fire. Also, there were plans to abolish the Slavonic Institute and combine its work with the Czech Language Institute; hence, the future and preservation of Murko's sound collection were uncertain. Therefore, in 1963, Vladimir called on the relevant Yugoslav institutions to request the cylinders and the supporting documents to be handed over for scholarly analysis and publication as it would have been unacceptable for the rich documentary material to perish (Murko 1963: 118-119). His efforts were not in vain and, in 1966, the Yugoslav Academy of Sciences and Arts in Zagreb received Murko's materials and stored it in its archives. The Zagreb-based Institute for Folk Art (today the Institute of Ethnology and Folklore Research), which was actively involved in the acquisition of the material, examined the collection and found that, in addition to photographs, negatives, and travel notebooks (a total of twenty-two small eight-format travel notebooks), it also contained seven boxes full of wax cylinders (the total number of cylinders was 138) and a phonograph (“broken”). As reported by Maja Bošković-Stulli (1966: 285-286), the sound recordings were extremely valuable, although they were much smaller in number compared to the number of actual recordings made. Also, it was not known how many of them were still technically usable. In the summer of 1967, the recordings were played back and copied on magnetic tapes thanks to the joint efforts of the Committee on Folk Life and Customs and the Institute for Folk Art. According to the report made about the copied recordings (IEF 1967), a total of 129 cylinders were copied (the rest were too damaged), and the recordings were technically of very poor quality because the cylinders were worn out and many of them damaged. The recordings on magnetic tapes were stored at the Institute of Folk Art, whereas the cylinders remained in the archives of the Yugoslav Academy of Sciences and Arts (today the Croatian Academy of Sciences and Arts). As part of systematic digitization of magnetic tapes, the sound material was digitized in 2002 by the Institute of Ethnology and Folklore Research and stored on CD-R discs.

Unfortunately, only a small amount of the digitized material from the preserved cylinders are recordings from Bosnia and Herzegovina.

\section{THE SOUND RECORDINGS HELPED MURKO GAIN NEW INSIGHTS INTO FOLK EPICS}

Even his earliest field sound recordings in 1912 and 1913 helped Murko gain some significant new insights about the research on folk epics. The recordings provided irrefutable evidence of singers swallowing vowels and even entire syllables at the ends of verses while singing, and of sometimes adding syllables to words. The most important finding, however, can be credited to the Vienna Phonogram Archive's rule stipulating that researchers must first write down the lyrics of a song before recording it. In doing so, Murko also discovered that singers changed small sections of songs during each performance (i.e., while singing for 


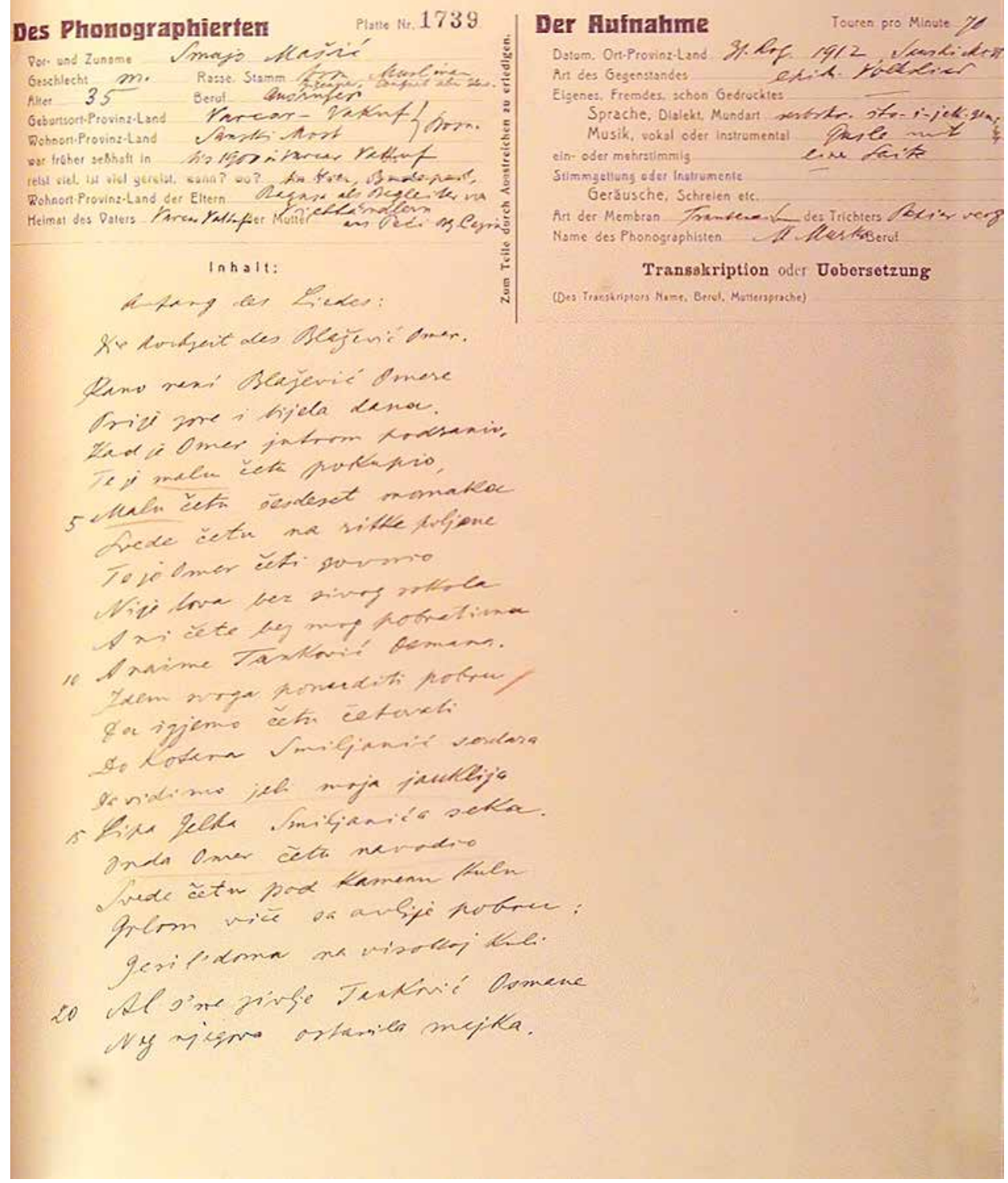

Murko’s protocol from the song "Rano rani Blažević Omere" (Early in the Morning Omer Blažević), protocol number 1939 (Phonogram Archive of the Austrian Academy of Sciences in Vienna). 
the lyrics to be written down, while rehearsing in front of the phonograph, while singing during actual recording), which no other researchers in Slavic territory had ever noticed and pointed out before. The differences in the lyrics were far from minor; in fact, entire verses or their numbers were changed, sometimes even the beginnings of songs. Even greater were the differences between the dictated song lyrics and the actual singing, because while dictating the singers quickly switched to narration (prose) or were unable to dictate slowly. In most cases, spoken songs had fewer verses than songs that were sung. Murko also pointed out the connection between the lyrics ${ }^{14}$ and the melody, as well as the importance of an instrumental accompaniment that offered singers a short break and allowed them to concentrate on performing the rest of the song (Murko 1951a).

Due to the technical limitations of the recording technology available at the time, Murko mostly recorded only the beginnings of songs; however, it turned out that the number of recorded verses was even smaller than he had first expected it to be. Because the discs had to be changed frequently, he was surprised to realize that the singers were unable to stop singing and then resume properly from the point of interruption. Therefore, when changing the disc, he generally asked the singers to start singing the song again from the beginning, and then he recorded only from the point in the song where he had run out of space on the previous disc. Murko gives an interesting description, comparing the singer to a barrel organ that plays the entire song before having to start all over again so that the listeners can hear a certain section of the song one more time. However, in doing so, the singer does not present the song in exactly the same way as before (Murko 1912: 7-8).

Murko was amazed at the singers' abilities and the skill of guslar players/singers, ${ }^{15}$ and wondered how it was possible to sing such long epics with great rapidity, without mistakes and with impeccable poetic creativity. He concluded that singers did not learn songs by heart, but were able to recreate or improvise them each time because of their knowledge of the language and folk poetics (Murko 1974: 169).

Murko's research showed that epic songs were performed by members of all ethnic groups of different ages, social classes, education, and interests. Talented singer-performers, whose interpretation was based on knowledge gained through oral experience and years of experience, stood out in particular. There had never been many good gusle players. For this reason, they were greatly appreciated and invited to all community celebrations as well as those organized within a particular household. On these occasions, they had creative

14 There were numerous difficulties in writing down the lyrics. The singing was sometimes incomprehensible, so the researchers who could not understand the local dialect made mistakes when documenting the songs. Murko's collaborators in the field, including prominent ethnographers and linguists Hamdija Kreševljaković and Hamid Dizdar, duly checked the texts sung, performed proofreading, and added explanations of archaic expressions and Turkish borrowings. They also paid great attention to accents that differed in singing from those of everyday speech and the specific pronunciation of the last syllable in a verse (cf. Murko 1912: 4).

15 A guslar is a singer of epic songs that accompanies himself on the gusle, and therefore in the article a guslar is sometimes characterized as an instrumentalist-a gusle player-and sometimes as a singer. 
freedom and were not limited by any (psychological) constraints. Every new performance represented a new interpretation of familiar material, so the songs were constantly updated. Therefore, Murko believed that singing to the accompaniment of gusle was a productive and not merely a reproductive type of art.

Gusle players formed their own repertoire, which most often included songs about events from their immediate surroundings. These entailed learning songs that they were already familiar with, but also the ability to "refine them according to their own opinions and taste" (Murko 1951a: 509). Thus, the singers did not learn songs by heart, but rather formed them according to their own singing skills and knowledge; that is, they recreated them. Transmission of songs by word of mouth necessarily involved a greater number of transmitters belonging to different times and social classes.

The guslar songs contained varied content: from heroic epics, folk ballads, and jokes, to stories from the local community and the guslars' own lives. Nevertheless, most of the guslar repertoire consisted of epic songs. Murko was the first researcher to create an epic song classification, dividing the songs into the following five categories:

- Krajišnice: songs that praise heroes of the Ottoman period,

- Licke: songs that were sung in the Bosnian Frontier, Lika, and were about the struggles of lička heroes,

- Undurske: ${ }^{16}$ songs that celebrate various occasions in Slavonia and Hungary,

- Hajducko-uskočke: songs about the hajduks (brigands), from the western border areas of the Ottoman Empire, and after the fall of Bosnia in 1463 and Herzegovina in 1482, about the uskoks (ambushers) that fled the Ottoman army, and

- Herzegovinian-montenegrin: songs reciting events related to the Battle of Kosovo (the pre-Kosovo and Kosovo cycles), as well as heroes from Herzegovina and Montenegro. Although he did not record other forms of folk music practice, Murko left notes about polyphonic singing, wedding songs, and narratives performed alongside the deceased. Even though he was focused on epic content, notably during his earlier research expedition in 1912 and 1913, he also became interested in a few informants who sang sevdalinke (plural; sing. sevdalinka), a type of urban love song. Thus, in northeastern Bosnia, he recorded two songs marked as ravna songs, ${ }^{17}$ which is one of the forms of sevdalinka. Murko was familiar with this particular type of sevdalinka from earlier research by Ludvik Kuba, which may have prompted him to record it again in Bijeljina as performed by Vladimir Stanišić and Suljo Vretenarević-Kafedžija. There is nothing in the commentary on the list of recordings other than the ravna label that would suggest which variants and styles of performance are included, and what verses are sung to these music patterns. In Tuzla, Murko recorded a

16 He heard from his informants that the Bosnia is located next to the Sava River, and Unđurovina is just across the Sava (Croatia). Murko explains that Unđurovina is Hungary (Murko 1951a: 223).

17 A special feature of the ravna songs of the urban traditional music practice of Bosnia and Herzegovina are the opening formulas of the tune, which determine the melodic models of the numerous variants of these songs. For those songs sung in ten-line verses, three basic models were observed. 
certain Ilija Četković, a bus driver, originally from Podgorica in Montenegro, who sang to him the sevdalinka "Poljem se vija oj zor delija" (In the Field Walks a Hero) and the song "Begovi jadi" (The Bey's Sorrows) composed on the model of the sevdalinka, which Murko himself indicated in the comments in the list of recordings.

Although at first one might think that the song "In the Fields Walks a Hero" belongs to the repertoire of Bosnian sevdalinke, given the location of the recording and the residence of the informant, the song recorded by Murko tells otherwise. From the relatively well-preserved recording, it can be concluded that the melodic structure is accomplished by repeating the verse (AA) in ten symmetric syllables (i.e., five and five). However, the melody of the song performed by Četković, or the tonal relations that can be clearly heard, suggest that it is a Montenegrin singing-poetic form that the informant maintained. In exploring this part of Murko's material, a fortunate circumstance is contained in the fact that a relatively well-preserved recording was available. Otherwise one might think that this is a song very similar to the song "Poljem se vija Hajdar delija" (In the Field Walks Hajdar the Hero), which was sung in the early twentieth century in Stolac. The song was documented in Stolac in 1893 by Ludvik Kuba and subsequently published in the Glasnik Zemaljskog muzeja Bosne i Hercegovine (Journal of the National Museum of Bosnia and Herzegovina; Kuba 1909: 594). It is possible that, as was the case with ravna songs, Murko was familiar with the song from Kuba's work, and decided to record it in Tuzla.

\section{POLJEM SI VIJA ZOR DELIJA}

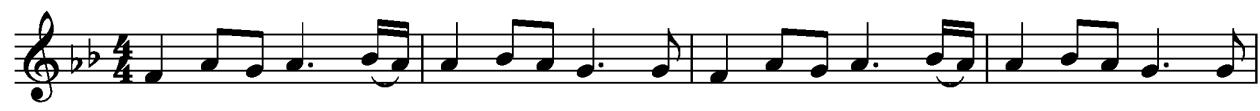

Po-ljem se vi - ja oj, zor de-li - ja po-ljem se vi - ja oj, zor de-li - ja

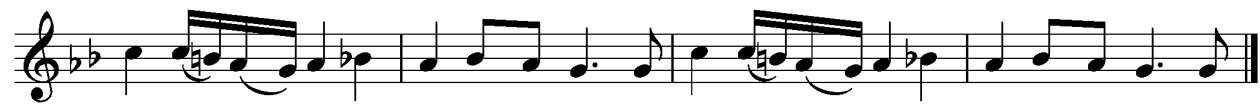

po ra - vnom po-lju na vra-nom ko- nju po ra - vnom po-lju na vra-nom ko - nju

Transcription of the song "Poljem se vija oj zor delija" (In the Field Walks Hajdar the Hero), sung by Ilija Četković (Recorded by Matija Murko in Bijeljina, 1930).

\section{THE FUNCTION AND OCCASIONS OF PERFORMING EPIC SONGS}

It was already during his preparations for the sound recordings, even before leaving to do field research, that Murko decided to study singing in the performers' home environment, providing that the available technology would allow it. This was especially noticeable during his preparations for the 1930-1932 field research, when, despite some concerns about the 
quality of the recordings, he opted for a relatively simple, small, and easily portable Edison phonograph, which required no electricity and could be used both indoors and outdoors. Murko felt that his experience in the field showed that his choice of a device turned out to be a good one (Murko 1951a: 533). Murko thus recorded in various places and on various occasions: from evening house parties and cafés to open public places such as squares, where local fairs were held.

In addition to focusing on his methodology of recording singers in their own home environments, Murko paid special attention to where and on what occasions epic songs were sung. Thus, the significance of his research certainly lies in his historiographically and ethnographically rich descriptions of life in Bosnia and Herzegovina as well as in other Balkan countries (Dukić 1995: 57).

Murko noted that gusle players, like all real artists, usually sing during the day when they are alone in the house or during the evenings when the whole family gathers by the fireplace. Good gusle players often showed the art of playing at sijela, which were nightly gatherings of a group of villagers in a house, where the sounds of gusle could be heard during long winter nights. People would listen to the singing accompanied by the gusle and talk about the songs' creation and content. It was the custom in rural Muslim communities during the month of Ramadan ${ }^{18}$ to spend all night from iftar (the evening meal) to sehur (the morning meal before fasting) listening to singing accompanied by gusle. Celebrating Catholic holidays ${ }^{19}$ also included singing to the accompaniment of gusle. Murko noted that the priests from the Franciscan monastery in Široki Brijeg went to the villages to serve Christmas Mass. In the house where the priest was at night, a hundred people would gather and stay late into the night, rejoicing while listening to the gusle (Murko 1951a: 347). Celebrations of the family patron saint, as a particularly significant religious holiday among the Orthodox population, were very common at that time. Celebrations were always accompanied by singing along with the gusle. In some areas, especially around Sarajevo, singing was performed in groups. The gusle player played and began singing the song, and then others continued to sing along with the guslar.

By performing a familiar repertoire or creating new tunes, the guslar was able to communicate directly with the listeners. The audience, on the other hand, knew how to appreciate the performer's organizational and musical skills. This practice of celebrating religious holidays in all ethnic groups in the villages of Bosnia and Herzegovina continued until the mid-twentieth century.

As venues of particular importance, Murko cites cafés, especially those created during the Ottoman rule: the a la turca cafés dominated by "oriental" sociocultural values. As

18 Ramadan is the ninth month of the Islamic calendar. It is the month of fasting, which means abstaining from eating and drinking, bad words and bad behavior, and other things forbidden in Islam. Fasting is from dawn until sunset.

19 Murko specifically mentioned Christmas, the feast of St. Stephen, the New Year, and the feast of the Three Kings. 
the main public places for members of the middle or lower classes, cafés were relieved of strict social norms. They had a pleasant atmosphere for drinking coffee, casual conversations, and reading newspapers, but they were also a place where various deals were made. In a 1912 survey from Bosnia and Herzegovina, Matija Murko mentions professional folk musicians that played in cafés. These musicians were gusle players, as well as tambura and violin players (Murko 1912: 11-17). During his last trip, Murko noted that the cafés were a place suitable for entertaining and socializing, but also a place where traditional folk music, played mostly by professional folk players, could be heard.

The main places of singing in public were cafés (kafane) and bars. Cafés are commonly called both kafana and kavana, but also kava and kahva. The most typical cafés are in Bosnia and Herzegovina. Their interior is very simple. Couches, on which cushions filled with wool or straw are placed, are located near the wall and on the opposite side, with blue or red linen spread on top of them. A better and larger cushion is placed only at the corner of the couch: the place where the agha or bey sits when visiting the café every day. In southeastern Bosnia, in Višegrad, gusle were common in Orthodox cafés until the First World War (1914), whereas today they can be found mostly among Muslims. However, in the nearby town of Rogatica, gusle can be found in seven Orthodox and four Muslim cafés where peasants gather for some singing when they come to the city. (Murko 1951a: 354)

Murko mentioned that gusle were played by café guests, singers "invited by innkeepers, peasants, intellectuals," and singers who "come alone on certain days, especially fair days, to entertain others with their skills and enjoy the hospitality" (op. cit.: 355). He mentions in particular the teamsters ${ }^{20}$ and their singing in cafés and inns. ${ }^{21}$ Cafés and inns were meeting places for singers, and competitions in singing accompanied by gusle were often held there. Murko mentioned Avdija Oprašić from Višegrad as an individual that travelled “as a teamster to Zvornik, Sarajevo, Foča, and Čajniče," where he met good singers from Herzegovina and also sang in the cafés where there were gusle players (op. cit.: 356). Murko concluded that blind gusle players and teamsters were the most significant transmitters of epic folk songs.

Most of the gusle players he recorded were professional musicians that performed at beys' houses. ${ }^{22}$ Murko noted that he had found "very interesting remnants of Bosnian

20 A teamster (kiridžija) is a person who transported goods on horse and ox carts from one place to another.

21 An inn ( $h a n$ ) was a facility for overnight lodging of travelers, caravans, and teamsters. They usually had ground-level rooms that served as stables and an upper floor that housed a restaurant and sleeping quarters. It is interesting to note that, unlike cafés, inns served alcoholic beverages.

22 These were residential mansions of rich and influential people in Bosnia and Herzegovina (in the time span from Ottoman rule to the twentieth century). 
feudalism and epic poetry: rich beys and aghas had permanent gusle players or had players staying with them for months, and they were richly rewarded for their services" (Murko 1951a: 362). During the Ottoman and later Austro-Hungarian empires, professional folk musicians were invited to play in the homes of rich people, so their status could be compared to that of players in the medieval Bosnian feudal castles or players described by Homer. Murko cites the examples of Muharem-beg Pašić from Bijeljina, who had players accompany him wherever he went, Osman-beg Salihbegović, who kept players in his service for six months at a time, Ešer-beg from Zvornik, who called for players for the sake of his guests, and Šahinpašić from Sokolac, who had bey singers stay with him for two or three days, and better players even longer (op. cit.: 365). Murko found it important to highlight the individuals he recognized as good singers and players, but also as experts in local music practice.

One such singer was Ibrahim Vrabac (Knežina, Eastern Bosnia, 1852). In his younger days, Vrabac served the aforementioned bey Šahinpasić, who often listened to the playing of professional folk musicians in his own house. During his journeys with the bey, Ibrahim Vrabac had the opportunity to listen to other singers' performances. At the young age of 19, he himself became a bey singer. In addition to the extremely rich and varied repertoire he interpreted, Vrabac also shared some very important information about the origins of certain songs, as well as about the gusle players from whom he had learned those songs. Murko was particularly interested in Vrabac's moral views. Specifically, Vrabac had to pay for transportation to the recording location and his lodging, so Murko offered him money for his expenses and compensation for his singing. Vrabac replied: "Are you a scholar or a trader? If you are a scholar, I will not take anything from you, because it is haram (a sin) to me. If you are spreading knowledge in the world, it is our duty to help you as much as we can" (Murko 1951a: 113-114). The story of Ibrahim Vrabac is just one of the many interesting stories documented by Murko, revealing a great deal of information relevant to ethnomusicological research.

\section{CONCLUSION}

Matija Murko undertook his research and recording in Bosnia and Herzegovina in a very comprehensive and systematic manner, covering a rather long period of time. He made sure to document his field research very well, using modern technical devices, sound recordings, photography, and new methodological approaches to do so. It therefore comes as no surprise that Murko's research findings soon won the praise of many contemporary researchers, who studied his recordings and other collected field material with fascination, acknowledging his outstanding contribution to the research and documentation of folk epics. It is important to note that Murko was the first European researcher to document detailed data on informants. Some of these informants later worked with Milman Parry 
and Cvjetko Rihtman, which makes it possible to trace the continuity of their musical performances as well as changes in their repertoires.

Unfortunately, subsequent ethnomusicologists in Bosnia and Herzegovina (up to 1991) did not refer to the research conducted by either Matija Murko or other researchers, and based their knowledge mostly on their own research. This was mainly due to two reasons: some of the previous research (Krauss, Murko, and Parry's recordings), was either not available to Bosnian researchers or they did not trust the research of foreign researchers in terms of sufficient knowledge of Bosnian music tradition, language, and culture.

New research on Matija Murko's fieldwork has shown that he left his remarkable stamp on the study of certain forms, especially epic songs accompanied by gusle, the singing of ravne songs, and sevdalinke accompanied by the violin. Murko's sound recordings are the first, and in some cases, the only material evidence of the existence of particular forms that once occupied a prominent place in the folk music tradition of Bosnia and Herzegovina. One such example is the sevdalinke performed with the violin accompaniment, which has been absent from live folk music practice since the mid-twentieth century. Singing accompanied by the gusle was once functionally related to certain customs. At the end of the twentieth century, there were significant social changes that influenced the way of life, the function of singing accompanied by gusle, and the perception of this practice in the postwar contexts of Bosnia and Herzegovina. The older guslar repertoires are still performed today, but in much shorter variants than the ones performed by the gusle players on Murko's recordings. Moreover, for ethnomusicologists and researchers of folk literature, Murko's recordings are extremely important because they contain a way of performing epic songs that can no longer be found in live folk music practice. Studies of the legitimacy of the meter in folk poetry have shown that in our dominant epic decasyllable, attention is drawn to odd syllables. The ninth syllable attracts the accent, even if it occurs at the place of the second syllable of the three-syllable rate. In these cases, the accent shifts from the first to the second syllable. When two monosyllabic words are placed next to each other, the accent is attracted by the first monosyllabic word or, if a monosyllabic word and a two-syllable word are placed together, the accent is attracted by the monosyllabic word. However, this is not the case when one- and two-syllable rates appear at the end of a ten-line verse. In this case, the one-syllable binds to the previous article, forming a four-syllable rate, and the two-syllable becomes a self-contained article with an emphasis on the first syllable, which is, in fact, the ninth syllable of the ten. Maretić (1907) and Jacobson's (1966) theories can clearly differ in the performances Murko recorded during 1912 and 1913. It is also important to add that singers often tied the last, tenth syllable to the first syllable of the next verse. Recent research has shown that this way of interpreting epic songs is no longer present in folk music practice (Talam and Karača 2016: 513).

It is important to mention that Murko's research covered the guslar practices of all ethnic groups in Bosnia and Herzegovina: Bosniaks, Serbs, and Croats, whom he referred to as "Muslims, Orthodox, and Catholics." Therefore, Murko's recordings and other collected 
material are very significant evidence of the diversity and presence of this music practice among all ethnic groups in Bosnia and Herzegovina. In the postwar years (after 1995) in Bosnia and Herzegovina, singing accompanied by gusle was mostly associated with members of one ethnic group - Serbs and, to a lesser extent, Croats - for abusing this musical practice in promoting wartime and destructive political ideas. The consequence of this process is that singing accompanied by gusle is extinct in the Bosniak music practice, while sevdalinke and ravna songs occupy an increasingly important place in different performance contexts.

Introducing Matija Murko's research to the broader scholarly and artistic community opens up possibilities for a better understanding of epic and lyrical music practices in a wider historical context, as well as a change in the perception of performing certain forms in recent musical practices of Bosnia and Herzegovina.

\section{SOURCES}

IEF. 1967. A letter written by Maja Bošković-Stulli to Odbor za narodni život i običaje and to the Arhiv Jugoslavenske akademije znanosti i umjetnosti, dated 15 June 1967. Arhives of the Institut za etnologijo in folkloristiko, file 1967/1, no. 224/1, Zagreb: Institut za etnologiju i folkloristiku.

K. A. 1937. Naučna ekspedicija sa dr. Gezemanom na čelu snimila je u Sarajevu naše narodne pesme. Jugoslavenska pošta, Oct. 7th, 1937.

SMB. 1930. A letter written by Gustav Becking to Erich von Hornbostel, dated Nov. 19th, 1930. Berliner Phonogramm-Archiv: Historische Akten. Staatliche Museen zu Berlin, Ethnologisches Museum.

SMB. 1931a. A letter written by Gustav Becking to Erich von Hornbostel, dated July 16th, 1931. Berliner Phonogramm-Archiv: Historische Akten. Staatliche Museen zu Berlin, Ethnologisches Museum.

SMB. 1931b. A letter written by Erich von Hornbostel to Gustav Becking, dated Aug. 8th, 1931. Berliner Phonogramm-Archiv: Historische Akten. Staatliche Museen zu Berlin, Ethnologisches Museum.

SMB. 1931c. A letter written by Matija Murko to Erich von Hornbostel, dated May 10th, 1931. Berliner Phonogramm-Archiv: Historische Akten. Staatliche Museen zu Berlin, Ethnologisches Museum.

\section{REFERENCES}

Bošković-Stulli, Maja. 1966. Tragom ostavštine Matije Murka. Narodna umjetnost 4: 285-287.

Buturović, Đenana. 1991. Tragom proučavanja muslimanske epike Matije Murka (Uz 130-godišnjicu rođenja i 40-godišnjicu smrti uglednog slaviste, 1861-1951). Glasnik Zemaljskog muzeja Bosne i Hercegovine u Sarajevu: Etnologija 46: 7-35.

Čubelić, Tvrtko. 1971. Uvodne napomene. In: Cvjetko Rihtman (ed.), Rad 15. kongresa SUFJ. Sarajevo: Udruženje folklorista Bosne i Hercegovine, 161-196.

Dukić, Davor. 1995. Razotkrivanje epskoga života: Murkov pristup južnoslavenskoj narodnoj epici. In: Rajko Muršič and Mojca Ramšak (eds.), Razvojslovenske etnologije od Štreklja in Murka do sodobnih etnoloskih prizadevanj: Zbornik prispevkov s kongresa, Ljubljana, Cankarjev dom, 24.-27. oktober 1995. Ljubljana: Slovensko etnološko društvo, 51-57. 
Jakobson, Roman. 1966. O strukturi stiha srpskohrvatskih narodnih epova / Über den Versbau der serbokroatischen Volksepen. In: Milka Ivić and Sreten Marić (eds.), Lingvistika i poetika. Belgrade: Nolit, $148-153$.

Kuba, Ljudevit. 1909. Pjesme i napjevi iz Bosne i Hercegovine. Glasnik Zemaljskog muzeja Bosne i Hercegovine 21: 581-602.

Lechleitner, Franz, and Johannes Spitzbart. 2017. Technical comments. In: Christian Liebl and Gerda Lechleitner (eds.), Epic Folk Songs from Bosnia and Herzegovina: The Collection of Matija Murko (1912, 1913). Tondokumente aus dem Phonogrammarchivs, Series 16. OEAW PHA CD: 40.

Liebl, Christian, and Gerda Lechleitner (eds.). 2017. Epic Folk Songs from Bosnia and Herzegovina: The Collection of Matija Murko (1912, 1913). Tondokumente aus dem Phonogrammarchivs, Series 16. OEAW PHA CD: 40.

Maretić, Tomislav. 1907. Metrika narodnih naših pjesama. Zagreb: Jugoslavenska akademija znanosti i umjetnosti.

Marjanović, Luka. 1898. Junačke pjesme (Muhamedovske): III knjiga. Zagreb: Matica hrvatska.

Murko, Matthias. 1909. Die Volksepik der bosnischen Mohammedaner. Zeitschrift des Vereinsfür Volkskunde 19: $13-30$.

Murko, Matthias. 1912. Bericht überphonographische Aufnahmen epischer, meinst mohammedanischer Volkslieder im nordwestlichen Bosnien im Sommer 1912. Vienna: Kaiserliche Akademie der Wissenschaften in Wien. (30. Mitteilung der Phonogrammarchives-Kommission).

Murko, Matthias. 1915. Bericht über phonographische Aufnahmen epischer Volkslieder im mittleren Bosnien und in der Herzegowina im Sommer 1913. Vienna: Kaiserliche Akademie der Wissenschaften in Wien. (37. Mitteilung der Phonogrammarchives-Kommission).

Murko, Matija. 1924. Gusle i tamburica sa dvije strune. In: Mihovil Abramić and Viktor Hoffiller (eds.), Bulićev zbornik: Naučni prilozi posvećeni Franu Buliću prigodom LXXV godišniice njegova života od učenika iprijatelja IV. oktobra MCMXXI.Zagreb: [Štampala Zaklada tiskare Narodnih novina], 683-687.

Murko, Matija. 1951a. Tragom srbsko-hrvatske narodne epike: Putovanja u godinama 1930-1932. Zagreb: Jugloslavenska akademija nauka i umjetnosti.

Murko, Matija. 1951b. Spomini. Ljubljana: Slovenska matica.

Murko, Matija. 1974. Epska narodna poezija u Jugoslaviji početkom XX vijeka. In: Đenana Buturović and Vlajko Palavestra (eds.), Narodna književnost Srba, Hrvata, Muslimana i Crnogoraca: Izbor studija i članaka. Sarajevo: Svjetlost, 163-164.

Murko, Vladimir. 1963. Sudbina literarne ostavštine i fonografskih snimaka srpskohrvatskih epskih pjesama Matije Murka. Narodna umjetnost 2 (1): 107-137.

Rihtman, Cvjetko. 1953. Narodna muzička tradicija jajačkog sreza. Bilten Instituta za proučavanje folklora Sarajevo 2: 5-102.

Talam, Jasmina. 2016. Traditional Folk Music in Bosnia and Herzegovina through Historical Sound Recordings. 47th Conference of the Kommission zur Erforschung musikalischer Volkskulturen. Seeon, Oct. 4th-9th, 2016 (in press).

Talam, Jasmina, and Tamara Karača Beljak. 2016. Matija Murko i njegova istraživanja u Bosni i Hercegovini. In: Fatima Hadžić (ed.), Zbornik radova 9. medunarodnog simpozija "Muzika u društvu". Sarajevo: Muzička akademija i Muzikološko društvo FBiH, 505-518.

Ziegler, Susanne. 2000. List of the Berlin Phonogramm-Archiv's Cylinder Collections. In: Artur Simon (ed.), The Berlin Phonogramm-Archive 1900-2000: Collections of Traditional Music of the World. Berlin: VWB - Verlag für Wiessenschaft und Bildung, 228-238. 
Ziegler, Susanne. 2006. Die Wachszylinder des Berliner Phonogramm-Archivs. Berlin: Staatliche Museen $\mathrm{zu}$ Berlin.

\section{POMEN RAZISKAV MATIJE MURKA ZA RAZUMEVANJE GLASBENE TRADICIJE V BOSNI IN HERCEGOVINI}

Vprispevku sta z različnih vidikov predstavljena raziskovanje in zvočno dokumentiranje Matije Murka v Bosni in Hercegovini, pri čemer je v ospredju pomen njegovih zvočnih posnetkov, ki so labko danes izjemni dokumentarni viri, še posebej v povezavi z izčrpnim dodatnim terenskim rokopisnim in drugim gradivom. Murko se je namrec raziskovanj in snemanja $v$ Bosni in Hercegovini lotil zelo celovito, sistematično in v daljšem obdobju; v razlicnih krajih Bosne in Hercegovine je preučeval ljudsko epiko v letih 1909, 1912, 1913, 1930 in 1931. Terenske raziskave je zelo dobro dokumentiral ter pri tem pogosto uporabljal tudi sodobna tehnična sredstva, zvočna snemanja in fotografiranje, in nove metodološke pristope. Čeprav zaradi objektivnih in finančnih razlogov ni mogel uporabljati snemalnih naprav na vseh terenskih potovanjih, je zbral veliko zvočnih posnetkov, ki jih labko razdelimo na dva dela: dunajsko gradivo s potovanj $v$ letih 1912 in 1913 (posnetih 82 fonografskih plošč) in praško gradivo s potovanj v letih 1930-1931 (posnetih 349 voščenih valjev); žal je bilo precej gradiva pozneje poškodovanega, uničenega in izgubljenega. Namen snemanj, snemalni postopek in potek snemanj so bili pri vseh potovanjih podobni, predvsem pa se oba sklopa posnetkov razlikujeta po vrsti snemalne aparature in zvočnem nosilcu: fonografskih ploščah in voščenih valjih. Različni sta tudi usodi posnetkov, saj so bili dunajski posnetki ves čas v rokah arhivske ustanove, ki je specializirana za zaščito in obdelavo zvočnega gradiva, medtem ko so bili praški posnetki prepuščni bolj nestrokovni arhivski oskrbi.

Nad rezultati Murkovih raziskovanj so bili navdušeni številni raziskovalci njegovega časa; z občudovanjem so preučevali posnetke in drugo zbrano terensko gradivo ter priznavali Murku izjemen prispevek k raziskovanju in dokumentiranju ljudske epike. Kljub temu so bile Murkove raziskave in terensko gradivo med raziskovalci v Bosni in Hercegovini več desetletij spregledane in med etnomuzikologi skoraj povsem nepoznane. Šele nedavno preučevanje Murkovega terenskega gradiva je pokazalo, da gradivo omogoča pomemben pogled na izvajalsko prakso nekaterih glasbenih oblik, še posebej epskih pesmi ob igranju gusel, izvajanja sevdalink ob spremljavi violine in petja t. i. ravnih pesmi. Njegovi posnetki so večkrat najstarejši in občasno tudi edini zvočno dokumentiran dokaz o obstoju nekaterih glasbenih oblik, ki so imele nekdaj pomembno mesto $v$ ljudski glasbeni tradiciji Bosne in Hercegovine, danes pa jih v glasbeni praksi ni več zaslediti. Murko je bil tudi prvi raziskovalec, ki je v Bosni in Hercegovini podrobneje dokumentiral podatke o izvajalcih; nekateri od njih so bili pevci tudi poznejsim raziskovalcem, kar omogoča spremljanje kontinuitete njihovih glasbenih izvedb in spremembe repertoarja. Posebej je potrebno poudariti, da je Murko raziskoval (guslarsko) epsko glasbeno prakso vseh narodov v Bosni in Hercegovini, tj. Bošnjakov, Srbov in Hrvatov, zato so njegovi posnetki in drugo zbrano gradivo 
pomemben dokaz takratne raznovrstnosti in razširjenosti te glasbene prakse med različnimi etničnimi skupinami v Bosni in Hercegovini. V letih po razpadu Jugoslavije je prišlo glede tega do korenitih sprememb: v glasbeni praksi Bošnjakov se petje ob guslah vse bolj izgublja in se povezuje predvsem s pripadniki srbske etnične skupine, v ospredju pa je petje sevdalink.

Assist. Prof. Dr. Drago Kunej, senior research fellow ZRC SAZU, Institute of Ethnomusicology

Novi trg 2, SI - 1000 Ljubljana, Slovenia, drago.kunej@zrc-sazu.si

Prof. Dr. Jasmina Talam

Academy of Music, University of Sarajevo

Josipa Stadlera 1/II, 71000 Sarajevo, Bosnia and Herzegovina, jasmina.talam@mas.unsa.ba

Prof. Dr. Tamara Karača Beljak

Academy of Music, University of Sarajevo

Josipa Stadlera 1/II, 71000 Sarajevo, Bosnia and Herzegovina, tamara.karaca-beljak@mas.unsa.ba 